\title{
Evaluation of Anti Ulcer Activity of Ethanolic Extract of Aegle Marmelos Leaves on Rats
}

\author{
Dr. Sharmin Rahman, Dr. Mohammad Rezaul Quader, Dr Rayhana Sharmin, \\ Dr Azmary Momtaz, Dr Khaleda Sharmin, Dr. Eliza Omar Eva, \\ Dr. Abu Syed Md. Mosaddek,
}

${ }^{1}$ Assistant Professor, Department of Pharmacology and Therapeutics, Ibrahim Medical College, Dhaka, Bangladesh.

${ }^{2}$ Lecturer, Department of Biochemistry, Shaheed Suhrawardy Medical College, Dhaka, Bangladesh.

${ }^{3}$ Lecturer, Department Pharmacology and Therapeutics, Uttara Adhunik Medical College, Dhaka, Bangladesh.

${ }^{4}$ Assistant Professor, Department of Pharmacology and Therapeutics, Delta Medical College, Dhaka, Bangladesh.

${ }^{5}$ Assistant Professor, Department of Pharmacology and Therapeutics, University Dental College, Dhaka, Bangladesh.

${ }^{6}$ Associate Professor, Department of Pharmacology and Therapeutics, Dhaka Medical College, Dhaka, Bangladesh.

${ }^{7}$ Professor and head, Department of Pharmacology and Therapeutics, Uttara Adhunik Medical College, Dhaka, Bangladesh (Correspondent).

\begin{abstract}
Background: Peptic ulcer disease is a serious gastrointestinal disorder that requires a well targeted therapeutic strategy. A number of drugs including proton pump inhibitors and $\mathrm{H}_{2}$ receptor antagonists are available for the treatment of peptic ulcer, but clinical evaluation of these drugs has shown incidence of relapses, side effects and drug interactions. Herbal medicine deals with plants and plant extracts in treating diseases. Bangladesh is a rich emporium of medicinal plants useful in treatment of various disorder including petric ulcer. Objective: Aegle marmelos is used as ethno medicine against various human ailments. Several crude extracts of this plants have been investigated and shown to have wide range of pharmacological effects. Although aqueous and other leaf extracts of Aegle marmelos have been studied for anti ulcer activity, no reports was found on ethanolic extract of leaves. Hence the present work was planned to investigate the anti ulcer actively, claimed traditionally. Materials and methods: The ethanolic extract of Aegle marmelos leaves at $400 \mathrm{mg} / \mathrm{kg}$ body weight was studied for ulcer protective activity by ethanol induced gastric ulcer method. Results: Ethanolic extract exhibited significant $(P<0.001)$ anti ulcer activity in ethanol induced gastric ulcer model used. Percentage protection of ulcer with ethanolic extract of Aegle marmelos was 56.33\% compared to standard anti ulcer drug Omeprazole (50.44\%). Conclusion: This present study indicates that ethanolic extract of Aegle marmelos leaves have potential anti ulcer activity.
\end{abstract}

Keywords: Aegle marmalos leaves, anti ulcer.

\section{INTRODUCTION}

Petric ulcer is one of the most prevalent gastro intestinal disorder, which effects approximately 5-10\% of people during their life. The major factors that causes peptic ulcer are infection with gram negative Helicobacter pylori, increased hydrochloric acid secretion, inadequate mucosal defence against gastric acid, drugs like the cholinergic drugs. NSAIDs and improper food intake ${ }^{1}$. In recent years, plentiful works have been carried out on herbal medicine to clarify their potential efficacy in gastric ulcer prevention and management.

Aegle marmelos commonly known as Bael is one of the indigenous plants that is readily available and has been traditionally used to improve gastro intestinal disorders. Extensive chemical investigations 
on various parts of the tree have been carried out. Many active constituents has been islolated and reported for analgesic, anti-diabetic, anti-inflammatory, anti-oxidant, anti-ulcer, anti-cancer, antimicrobial anti-hyperlipidaemic, redioprotective, antipyretic, and antispermatogenic activity ${ }^{2}$. Although aqueous and other leaf extracts of Aegle marmelos have been studied for antiulcer activity $^{3,4,5}$, no reports were found on ethanolic extract of leaves. Hence the present work was planned to investigate the antiulcer activity, claimed traditionally.

\section{Materials and methods}

The study has been performed in the department of Pharmacology at Dhaka medical college, Dhaka. 30 Wister Albino Rats of either sex, weighing between 100-150g were kept under standard condition of light and temperature, fed with standard rat pellet diet and allowed to drink water ad libitum.

\section{Plant material and preparation of extract:}

The leaves of Aegle marmelos were collected from Botanical garden, Mirpur, Dhaka. The plant was indentified and authenticated by the Bangladesh National Herbarium, Mirpur, Dhaka. The DACB accession number is 39510. The collected leaves $(1 \mathrm{~kg})$ Aegle marmelos were sun dried and the dried material was crushed to coarse powder with mechanical grinder.

Ethanolic extract was made in the Drug Research Laboratory of Center for Advanced Research of Science (CARS) of Dhaka University. The powdered plant material was soaked in ethanol (2L) with continuous shaking (40rmp) at $25^{\circ} \mathrm{C}$ for 3 days and filtered by filter paper. The ethanol extract was evaporated under vacuum rotator evaporator at $35^{\circ} \mathrm{C}$ temperature and in reduced pressure to obtained final semi solid extract. A total of 30 gram extract was found in this way.

Experiment Design: Ethanol induced gastric ulcer model.

The anti ulcer activity of ethanolic extract of Aegle Marmelos Leaves was performed by ethanol induced ulcer model ${ }^{6,7,8}$. Gastric ulcer was induced by administering ethanol $(1 \mathrm{ml} / 200 \mathrm{gm})$. All the animals were fasted for 24 hours before administration of ethanol. Experimental animals were randomly selected irrespective of sexes and divided into 3 groups consisting of 10 rats in each group. Rats in group I, served as control group, received distilled water ( $5 \mathrm{ml} / \mathrm{kg}$ body weight) orally. Rats in group II received ethanolic extract of Aegle Marmelos leaves $(400 \mathrm{mg} / \mathrm{kg}$ body weight) orally. Rats in group III received omeprazole $(20 \mathrm{mg} / \mathrm{kg}$ body weight) as standard reference drug orally.

The gastric ulcer were induced in rats by administrating absolute ethanol $(90 \%, 1 \mathrm{ml} / 200 \mathrm{gm})$ orally, after 1hour of ethanolic extract of Aegle marmelos leaves and Omeprazole treatment. Rats were sacrificed 1 hour later with excess of ether. The stomachs were isolated, washed gently under clean water and cut open along the greater curvature. The stomach were then fixed in $10 \%$ formalin and ulcer scores were recorded using standard method.

Scoring of ulcer was made as follows

- 0 - Normal Coloured stomach

- 0.5 - Red coloration

- 1 - Spot ulceration

- 1.5 - Haemorrhagic streaks

- 2 - Ulcers

- 3 - perforation

Mean ulcer score for each animal was expressed as ulcer index.

\section{Percentage protection of ulcer}

Percentage protection was calculated using the following formula.

(Control mean ulcer index - Test mean ulcer index)

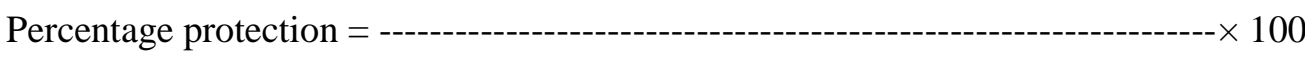

Control mean ulcer index. 


\section{Calculation of ulcer index:}

$$
\begin{aligned}
& \mathrm{UI}=\mathrm{U}_{\mathrm{N}}+\mathrm{U}_{\mathrm{S}}+\mathrm{U}_{\mathrm{P}} \times 10^{-1} \\
& \mathrm{UI}=\text { Ulcer index } \\
& \text { Un = Average of number of ulcers per animal } \\
& \text { Us }=\text { Average number of severity score } \\
& \mathrm{Up}=\text { percentage of animal with ulcers incidence }
\end{aligned}
$$

\section{Statistical Analysis}

All the results have been expressed as the mean \pm standard error of mean. The significance of the differences between treatment and control group were calculated using student's t-test.

\section{ReSUlts}

The mean ulcer score (mean \pm SEM) and ulcer index (mean \pm SEM) of control (vehicle treated, Group-I) were $2.83 \pm 0.21$ and $18.16 \pm 0.21$ respectively.

Ethanolic extract in dose of $400 \mathrm{mg} / \mathrm{kg}$ body weight produced a decrease in both ulcer score $(0.58 \pm 0.15)$ compared to control $(2.83 \pm 0.21)$ and ulcer index $(7.93 \pm 0.15)$ compared to control $(18.16 \pm 0.21)$. The difference in ulcer index were highly significant $(\mathrm{P}<0.001)$ statistically. Omeprazole $(20 \mathrm{mg} / \mathrm{kg}$ body weight $)$ also produced highly significant $(\mathrm{P}<0.001)$ decrease in ulcer index $(9.0 \pm 0.17)$ compared to control $(18.16 \pm 0.21)$. The results are shown in Table-I.

Table I. Effects of ethanolic extract of Aegle marmelos (Bael) leaves on ethanol induced gastric ulcer in rats-

\begin{tabular}{|c|c|c|c|c|}
\hline Group & $\begin{array}{c}\text { Number of rats } \\
(\mathrm{n})\end{array}$ & $\begin{array}{c}\text { Ulcer scoring } \\
(\text { mean } \pm \text { SEM) }\end{array}$ & $\begin{array}{c}\text { Ulcer index } \\
\text { (mean } \pm \text { SEM) }\end{array}$ & $\begin{array}{c}\% \text { Protection of } \\
\text { ulcer }\end{array}$ \\
\hline Group-I & 10 & $2.83 \pm 0.21$ & $18.16 \pm 0.21$ & \\
\hline Group-II & 10 & $0.58 \pm 0.15$ & $7.93 \pm 0.15^{* *}$ & $56.33 \%$ \\
\hline Group-III & 10 & $0.67 \pm 0.17$ & $9.0 \pm 0.17^{* *}$ & $50.44 \%$ \\
\hline
\end{tabular}

Note: Values are mean \pm SEM for 10 animals, $\mathrm{P}<0.001 * *$ compared to control group (Group-I).

Percentage protection of ulcer with $400 \mathrm{mg} / \mathrm{kg}$ body weight of ethanolic extract of Aegle marmelos leaves were $56.33 \%$ compared to standard anti ulcer drug omeprazole $(50.44 \%)$.

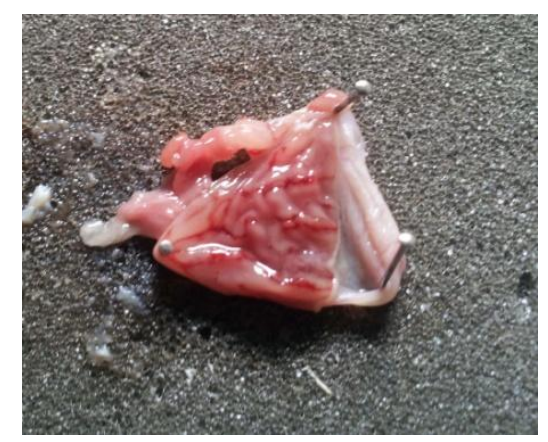

Figure 1. Photograph showing ethanol treated gastric mucosa of rat.

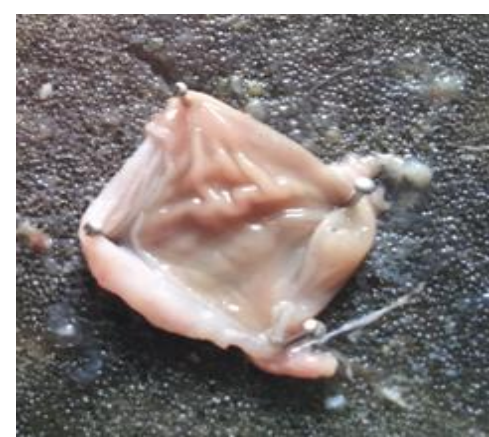

Figure 2. Photograph showing effect of ethonolic extract of Aegle marmelos leaves (400 mg/kg) body weight) on ethanol treated gastric mucosa of rat.

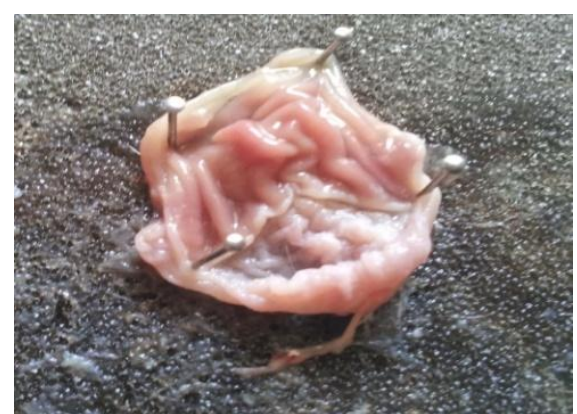

Figure 3. Photograph showing effect of omeprazole (standard drug) on ethanol treated gastric mucosa of rat. 


\section{DISCUSSION}

The experimental data of the study indicated ethanolic extract of Aegel marmelos leaves at $400 \mathrm{mg} / \mathrm{kg}$ body weight showed significant reduction in ulcer spots in the stomach when compared with control. The anti ulcer study was evaluated using ethanol induced gastric ulcer in rats. The ulcer index parameter was used for the evaluation of ulcer activity. Administration of ethanolic extract of Aegle marmelos and standard drug omeprazole both produced highly significant $(\mathrm{p}<0.001)$ anti ulcer effect compared to control group. Percentage protection of ulcer with $400 \mathrm{mg} / \mathrm{kg}$ body weight of ethanolic extract was $56.33 \%$ compared to standard anti ulcer drug omeprazole (50.44\%). Although ethanolic extract of Aegle marmelos leaves in the present study produced highly significant ulcer protection compared to anti ulcer drug omeprazole.

The study showed that ethanolic extract of Aegle marmelos leaves produced significant anti ulcer activity.

\section{Conclusion}

The observation and results of this study provide the information that ethanolic extract of Aegle marmelos leaves have ulcer protective effect which requires further experiment. It is recommended that further studies regarding pharmacokinetics, pharmacodynamics, toxicology and posology of ethanolic extract of Aegle marmelos leaves should be undertaken to develop it as a useful ulcer protective agent for human.

\section{REFERENCES}

[1] Harvey RA, Clark MA, Finkel R, Ray JA, Whalen K. Lippincotts Illustrated Reviews: Pharmacology, $5^{\text {th }}$ edition, Philadelphia: Lippincott Williams \& Wilkins. 2012; 351-356.

[2] Sharma PC, Bhatiya V, Bansal N, Sharma A. A review on Bael tree. Natural product Radiance, 2007; 6(2):171-178.

[3] Ilavarasan RJ, Monideen S, Vijayalakshmi M. Anti ulcer activity Aegle marmelos Linn, Ancient science of life, 2002; xxi:1-4.

[4] Madhu C, Hindu K, Sudepthi CD, Maneela P, Reddy KV, \& Bhagya Sree B. Anti ulcer activity of aqueous extract of Aegle marmelos leaves on rats. Asian J pharm Res, 2012; 2(4):132-135.

[5] Shenoy AM, Singh R, Samuel RM, Yedle R, \& Shabraya AR Evaluation of Anti ulcer activity of Aegle marmelos leaves extract. International Journal of pharmaceutical Sciences ad research, 2012; 3(5):1498-1501.

[6] Bhavani SR, Nagaraja PG, Badhusha F et al. A preliminary study on anti inflammatory and ulcer protective activity of ethanolic extract of Aegle marmelos (corr) leaves. Contemporary investigation and observation in pharmacy, 2012;1(1):40-43.

[7] Gupta J, Kumar D, Gupta A. Evaluation of gastric anti-ulcer activity of methanolic extract of Cayratia trifolia in experimental animals. Asian Pacific Journal of Tropical Disease, 2012;99102.

[8] Nwagba CA, Ezugwa CO, Eze CC, Anowi FC, Ezea SC, \& Nwakile CD. Anti ulcer activity of Bombax buonopozense P. Beauv. aqueous leaf extract, Journal of Applied Pharmaceutical Science, 2013;3(2):139-142. 